\title{
Cost Effectiveness of Erosion Control Covers during Vegetation Establishment under Simulated Rainfall
}

\author{
Ramandeep S. Sidhu ${ }^{1}$, Mark Dougherty'1, Wesley C. Zech ${ }^{2}$, Beth Guertal ${ }^{3}$ \\ ${ }^{1}$ Department of Biosystems Engineering, Auburn University, Auburn, USA \\ ${ }^{2}$ Department of Civil Engineering, Auburn University, Auburn, USA \\ ${ }^{3}$ Department of Crop, Soils and Environmental Sciences, Auburn University, Auburn, USA \\ Email: ${ }^{*}$ rzs0034@auburn.edu
}

Received 6 January 2015; accepted 26 January 2015; published 30 January 2015

Copyright (C) 2015 by authors and Scientific Research Publishing Inc.

This work is licensed under the Creative Commons Attribution International License (CC BY). http://creativecommons.org/licenses/by/4.0/

(c) (i) Open Access

\begin{abstract}
The main goal of this study was to quantify reduction of runoff responses using selected erosion control covers on $1.2 \mathrm{~m} \times \mathbf{0 . 6} \mathrm{m}$ plots under simulated rainfall to determine the most cost-effective temporary cover treatment under similar soils, rainfall and embankment slope conditions. The different erosion control covers tested were polyacrylamide (PAM), wheat straw and PAM (WS + P) with and without seed; and engineered fiber matrix (EFM) with and without seed. The EFM $+S$ and WS + P + S treatments were the most effective treatments for runoff volume with $68.0 \%$ and $48.9 \%$ reduction, respectively, as compared to control. $E F M+S$ was the most effective treatment for turbidity and modified total suspended solids (MTSS) with $\mathbf{9 8 . 7 \%}$, and $\mathbf{9 9 . 8 \%}$ reduction, respectively as compared to control. Vegetation in the wheat straw treatment significantly reduced turbidity but less effect on runoff volume and MTSS than vegetation in the EFM $+S$ treatment. Seeded treatments combined (EFM $+S$, WS $+P+S)$ had a significant negative correlation between MTSS delivery and time $(r=-0.69)$, as compared to a positive correlation of corresponding non-seeded treatments (EFM, WS $+P$ ) over time $(r=0.14)$. The EFM $+S$ treatment had $39 \%$ less average MTSS delivery than $W S+P+S$ but the $W S+P+S$ treatment $\left(\$ 1.03 \mathbf{~ k g}^{-1}\right.$ sediment reduction) was found to be $84 \%$ less expensive than the EFM $+S$ treatment ( $\$ 6.36 \mathrm{~kg}^{-1}$ sediment reduction). The WS $+P$ $+S$ treatment can therefore be recommended as the most cost effective method for sediment delivery reduction under similar conditions and within the limitations of this small scale plot study.
\end{abstract}

\section{Keywords}

Erosion, Sediment, Runoff, Turbidity, Vegetation, Water Quality

\footnotetext{
${ }^{*}$ Corresponding author.
}

How to cite this paper: Sidhu, R.S., Dougherty, M., Zech, W.C. and Guertal, B. (2015) Cost Effectiveness of Erosion Control Covers during Vegetation Establishment under Simulated Rainfall. Journal of Water Resource and Protection, 7, $119-129$. 


\section{Introduction}

"Soil erosion involves the breakdown, detachment, transport, and redistribution of soil particles by forces of water, wind, or gravity” [1]. A major water quality concern from erosion is nonpoint source pollution (NPS) which can be defined as pollution from diffuse sources driven by rainfall or snowmelt moving over or through the land [2]. Over 72 million metric tons (80 million tons) of sediment from construction sites end up in surface water bodies of the United States (US) each year [3]. The measured erosion rate from construction sites is 45 to 448 metric tons $\cdot \mathrm{ha}^{-1}$ (20 to 200 tons $\cdot$ acre $^{-1}$ ) per year, which is 3 to 100 times greater than erosion from croplands [4]. Forest road side slopes i.e. cut and fill slopes are one of the major source of erosion losses from managed forest systems [5]. Road construction creates bare and steep roadside slopes and lack of surface protection generates significant soil loss during storm events [6].

Various Best Management practices (BMPs) can be used to control and manage erosion and reduce sediment loading into water bodies [7]. BMPs used in this study are wheat straw, polyacrylamide (PAM), hydraulic applied mulch, and seeding. Harvested agricultural wheat straw or other available straw is widely used as a temporary erosion control cover until vegetation is established. Straw provides a high degree of ground cover when applied, reducing the impact of falling raindrops and preventing soil particle mobilization. Moreover, agricultural straw is inexpensive and easier to spread by hand or machine [8]. Straw was able to reduce soil loss by $96 \%$

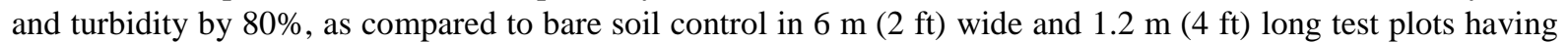
slope 3:1 under simulated rainfall intensity of $11.1 \mathrm{~cm} \cdot \mathrm{h}^{-1}\left(4.4 \mathrm{in} \cdot \mathrm{h}^{-1}\right)$ [9]. Wheat straw at an application rate of $2240 \mathrm{~kg} \cdot \mathrm{ha}^{-1}$ (1998 lbs $\cdot \mathrm{acre}^{-1}$ ) resulted in 100\% ground cover and 87\% reduction in erosion, as compared to control [10]. Straw reduced sediment yield by approximately $90 \%$, as compared to bare soil in $9.8 \mathrm{~m} \times 1.2 \mathrm{~m}$ (32 $\mathrm{ft} \times 4 \mathrm{ft}$ ) plots on a 35\% slope under $60 \mathrm{~mm} \cdot \mathrm{h}^{-1}\left(2.4 \mathrm{in} \cdot \mathrm{h}^{-1}\right)$ simulated rainfall intensity [11].

While field practices such as blown straw and straw mulch are an inexpensive and reliable form of erosion control, hydraulically applied mulches typically provide the highest level of erosion control on disturbed soils [12]. Hydraulically applied mulches have shown great improvement over the past 50 years in terms of technological advancement and increased environmental awareness and have become an efficient and widely used tool for erosion control, bank stabilization, and vegetation establishment [9]. "As a general rule, the more expensive hydromulches such as bonded fiber matrices (BFM), tend to offer better protection against erosion, but actual results are site specific” [13]. The application of mechanically bonded fiber matrix (MBFM) reduced average turbidity by approximately $85 \%$ and sediment loss by $86 \%$, as compared to bare soil under natural rainfall and reduced turbidity by $96 \%$, as compared to bare soil under simulated rainfall [14]. Hydro straw BFM was the most effective treatment having $99 \%$ average turbidity reduction and $100 \%$ sediment reduction, as compared to control in $1.2 \mathrm{~m} \times 0.6 \mathrm{~m}(4 \mathrm{ft} \times 2 \mathrm{ft})$ test plots under simulated rainfall intensity of $11.1 \mathrm{~cm} \cdot \mathrm{h}^{-1}\left(4.4 \mathrm{in} \cdot \mathrm{h}^{-1}\right)$ [9].

PAM can be an effective erosion and sediment control technique for reducing soil loss, decreasing runoff volume, increasing infiltration, and preventing surface crusting [15]. Dry PAM applied at a rate of $40 \mathrm{~kg} \cdot \mathrm{ha}^{-1}$ (35 lbs $\cdot$ acre $^{-1}$ ) resulted in $97 \%$ and $50 \%$ reduction in turbidity and eroded soil mass, respectively, as compared to control [16]. PAM applied as a dry powder at $20 \mathrm{~kg} \cdot \mathrm{ha}^{-1}\left(18 \mathrm{lbs} \cdot \mathrm{acre}^{-1}\right)$ reduced total suspended solids by $50 \%$, as compared to control [17]. Addition of PAM to straw resulted in a significant reduction of turbidity compared to cover treatments without PAM [14]. The application of PAM combined with wheat straw reduced runoff by $66 \%$, as compared to control [18]. The application of PAM at $22.5 \mathrm{~kg} \cdot \mathrm{ha}^{-1}\left(20 \mathrm{lbs} \cdot \mathrm{acre}^{-1}\right)$ and mulch applied to dry soil reduced sediment loss by 93\%, as compared to control [19].

Vegetation reduces water induced erosion by intercepting rainfall, increasing the infiltration rate of the soil, intercepting runoff at the soil surface and stabilizing the soil with roots [20]. Different percent of grass cover (35\%, 45\%, 65\% and 90\%) of a perennial black ryegrass (Lolium perenne L.) was grown and runoff reductions of $14 \%, 25 \%, 16 \%$, and $21 \%$ and sediment loss reductions of $81 \%$, $85 \%$, $87 \%$, and $94 \%$, respectively, were reported, as compared to bare soil [21]. Runoff and sediment from grass covered plots were reduced from $12.4 \%$ to $27.9 \%$ and $39 \%$ to $76 \%$, respectively, with an increase in percent vegetation cover, as compared to bare soil [22].

Private, commercial, and public land owners seek the most cost effective maintenance practices and technology to control erosion on earthen roadside embankments. This paper reports results from small scale field experiments using a sandy clay soil from Russell County, Alabama (AL) that evaluated runoff water quality response of selected temporary covers on 3:1 slope under simulated rainfall with and without vegetation. The experiment quantified the beneficial effect of selected cover treatments in roadside erosion control and water quality protec- 
tion using normalized unit cost comparisons. The specific objectives of this research were to: 1) Evaluate runoff volume, turbidity, and modified total suspended solids (MTSS) as affected by selected erosion control covers under simulated rainfall on a 3:1 slope; 2) Quantify the beneficial impact and benefits of seeded treatments over non-seeded treatments in terms of runoff volume, turbidity, and MTSS delivery; and 3) Evaluate the cost effectiveness of temporary covers for sediment yield reduction and offer general recommendations based on water quality and budget requirements.

\section{Materials and Methods}

This study was conducted on test plots designed to compare selected treatments under simulated rainfall with and without vegetation establishment. A 15-minute simulated rainfall was applied to six treatments that included a bare soil (BS) control as follows: Bare soil with PAM (BS + P), engineered fiber matrix (EFM), EFM with seed $(E F M+S)$, wheat straw with PAM $(W S+P)$, and $W S+P$ with seed $(W S+P+S)$. Data collection consisted of runoff volume, turbidity, MTSS, and percent vegetation cover. The percent vegetation cover was monitored to quantify the performance of the seeded treatments during the vegetation establishment period. Parametric and non-parametric tests were used to determine the significance between the treatments means on normal and non-normal data, respectively.

Approximately $3.4 \mathrm{~m}^{3}\left(120 \mathrm{ft}^{3}\right)$ of soil was excavated from a forested site in Russell County, AL with eroded earthen road embankments and transported by dump truck to the Turfgrass Research Unit (TGRU) at Auburn University, Auburn, AL. Transported soil was stored under tarps until use. Soil analysis was conducted by Auburn University Soil Testing Laboratory to determine soil texture and fertilizer recommendations for a grass cover. Soil textural analysis yielded $45.6 \%$ sand, and $38.1 \%$ clay, and $16.3 \%$ silt. The resulting textural class was identified as a sandy clay.

Test plots were lumber boxes constructed $0.6 \mathrm{~m}$ (22 in) wide, $1.2 \mathrm{~m}$ (47 in) long, and $0.1 \mathrm{~m}$ (5.5 in) deep placed on a 3:1 slope using cinder blocks under a galvanized steel frame hoop house $11 \mathrm{~m} \times 7.5 \mathrm{~m}(35 \mathrm{ft} \times 24 \mathrm{ft})$ (Figure 1) to protect plots from direct rainfall. A $0.3 \mathrm{~m}$ (12 in) rectangular weir was cut into the front face of each box to direct water flow into fabricated sheet metal flumes and into collection buckets.

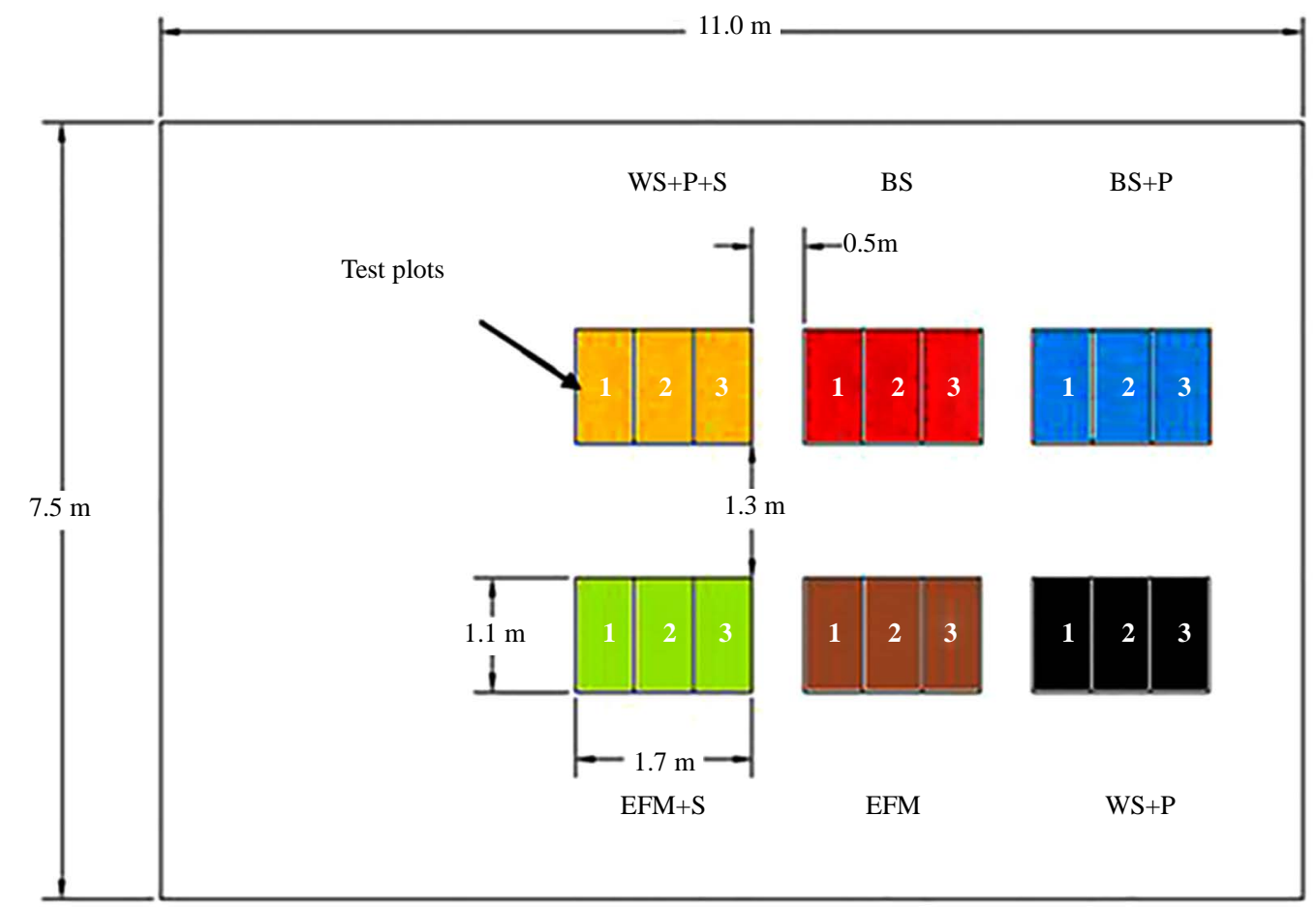

Figure 1. Experimental layout of test plots and treatments, Turf Grass Research Unit, Auburn, AL. Note: BS = Bare soil; BS + P = Bare soil with PAM; EFM = Engineered fiber matrix; EFM + S = Engineered fiber matrix with seed; WS $+\mathrm{P}=$ Wheat straw with PAM; WS $+\mathrm{P}+\mathrm{S}=$ Wheat straw with PAM and seed. 
Test soils were compacted to approximate the dry bulk density of the native soil as a suitable seed bed. Typical seedbed preparation provides loose soil to match the bulk density of the native soil in numerous studies [14]. To approximate native compaction in each test plot, a core sample was taken from the soil site in Russell County. Dry bulk density of the soil at the site was determined to be $0.9 \mathrm{~g} \cdot \mathrm{cm}^{-3}$. To approximate native soil density, a mold box of $25.4 \mathrm{~cm} \times 25.4 \mathrm{~cm}$ (10 in $\times 10 \mathrm{in}$ ) was constructed and filled with native soil tamped to achieve the same dry bulk density as the original soil. The number of hand tamps required to achieve a native dry bulk density was 60 . Testing and tamping of the soil was done with air dry soil, and no water was added to the soil while packing into the test plots.

The rainfall simulator in this study consisted of $1.9 \mathrm{~cm}(0.75 \mathrm{in})$ galvanized steel pipe, sprinkler nozzle, water filter, pressure regulator, pressure gauge, garden hose, and a ball valve. A rainfall simulator was fabricated with a sprinkler nozzle installed $3.0 \mathrm{~m} \mathrm{(10} \mathrm{ft)} \mathrm{above} \mathrm{the} \mathrm{ground} \mathrm{to} \mathrm{provide} \mathrm{a} \mathrm{rectangular} \mathrm{spray} \mathrm{area} \mathrm{of} 2.4 \mathrm{~m} \times 2.4 \mathrm{~m}$ $(7.9 \mathrm{ft} \times 7.9 \mathrm{ft})$. A Single FullJet ${ }^{\mathrm{T}}$ 1/2 HH-30WSQ spray nozzle manufactured by Spraying Systems Co. (Wheaton, IL) was used along with a Senninger ${ }^{\circledR}$ PMR-10 MF pressure regulator manufactured by Senninger irrigation Inc., (Clermont, FL). Nozzle operating pressure was set to 68.9 kPa (10 psi). An Arkal ${ }^{\circledR} 1.9$ cm (0.75 in) water filter manufactured by Arkal Filtration Systems, (Israel) was attached to the water inlet to prevent nozzle clogging during testing. A pressure gauge was placed after the water filter to monitor operating pressure and a brass ball valve was used to start and end testing. A uniform distribution is desirable for simulated rainfall on test plots [23]. Lowest distribution uniformity testing developed by the US Department of Agriculture-National Resources Conservation Services (USDA-NRCS) was performed to assure a uniform distribution of the rainfall during testing. Average lowest distribution uniformity was determined to be $73.5 \%$, which is considered good for a sprinkler system [24]. Simulated rainfall approximate the rainfall depth between a 2-year 15 minute and 2-year 30 minute storm event for the area.

EnviroPAM $^{\circledR}$ polyacrylamide distributed by Innovative Turf Solutions, (Cincinnati, OH) was used in this study. PAM was applied uniformly to test plots using a salt shaker at a manufacturer recommended application rate of $10 \mathrm{~kg} \cdot \mathrm{ha}^{-1}$ ( $9 \mathrm{lbs} \cdot \mathrm{acre}^{-1}$ ), equivalent to $0.70 \mathrm{~g}$ per plot. The recommended application rate of wheat straw [25] was reduced from $4480 \mathrm{~kg} \cdot \mathrm{ha}^{-1}$ (4000 lbs·acre ${ }^{-1}$ ) to $2240 \mathrm{~kg} \cdot \mathrm{ha}^{-1}$ (2000 lbs·acre ${ }^{-1}$ ) equivalent to $167 \mathrm{~g}$ per plot to prevent smothering of seed and to ensure proper germination. Wheat straw was weighed and applied by hand. The EFM tested as a temporary cover in this study was Promatrix ${ }^{\circledR}$ EFM manufactured by Profile Products (Buffalo Grove, IL). EFM was applied using a hydromulcher system and a precision applicator at the manufacturer's recommended application rate of $3362 \mathrm{~kg} \cdot \mathrm{ha}^{-1}\left(3000 \mathrm{lbs} \cdot \mathrm{acre}^{-1}\right.$ ) and applied using a precision gantry. Browntop millet (Panicum ramosum) seed was mixed with sand for hand distribution and incorporated into the soil at a recommended application rate of $45 \mathrm{~kg} \cdot \mathrm{ha}^{-1}$ (3.4 g per plot). Fertilizer and lime was also mixed with sand in a container and applied uniformly to the treatment surface. Hand watering was provided after the incorporation of seed, fertilizers and lime.

Data collected for this research included 1) runoff volume (ml), 2) turbidity in Nephelometric Turbidity Units (NTU), 3) MTSS (g), and 4) percent vegetation cover. Runoff, turbidity, and sediment generated from each plot during simulated rainfall was recorded as a function of time and vegetated cover. Collection buckets were covered to ensure that no water fell directly into the bucket during rainfall simulation (Figure 2).

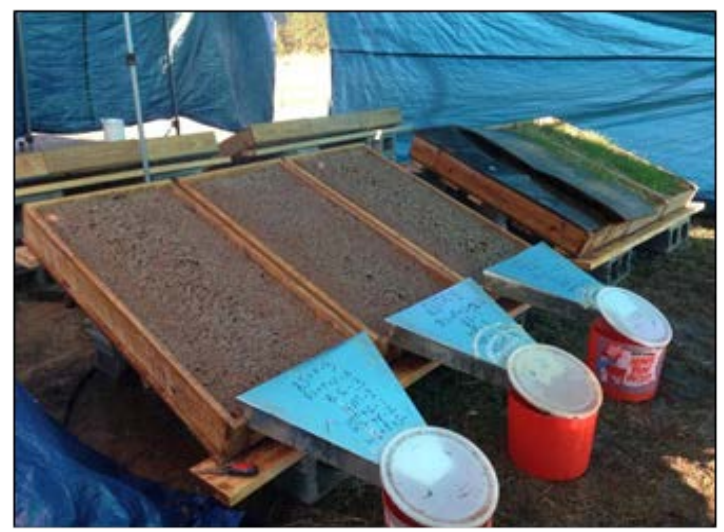

Figure 2. Collection of runoff from test plots, TGRU, Auburn, AL. 
Turbidity was measured with a Hach 2100 P turbidimeter (Loveland, CO). The turbidity of bare soil plots and bare soil with PAM treatments routinely exceeded the maximum reading on the turbiditimeter (>1000 NTU). As a result, samples were diluted as needed according to manufacturing recommendations to provide in-range turbidity results by dilution. All collected plot runoff samples were poured through a $1 \mu \mathrm{m}$ filter bag in the field. After filtration, filtered runoff from each test plot was poured into a graduated cylinder to determine the runoff volume. Standard method for total suspended solids method developed by US Environmental Protection Agency (USEPA 160.2) was used to determine MTSS [26]. Modifications from the standard method include the use of filter bags, rather than a filter of similar mesh accompanied by vacuum filtration in the laboratory. To determine MTSS, filter bags were dried at $105^{\circ} \mathrm{C}\left(221^{\circ} \mathrm{F}\right)$ for 24 hours and dry weight compared with oven dry weight of the bag prior to filtration. Percent vegetation cover was measured each day of rainfall simulation/runoff testing using the line transect method also known as line point intercept method. The line transect method was performed by stretching two strings having 25 equal marks from one side of the test plot diagonally to the other side. Each point represents a sample point to be tallied when viewed directly from above. Each plot was analyzed to determine the number of times a point hits the target grass species. The percentage vegetation cover was determined dividing the number of hits of target grass species by the total number of points.

JMP 11 [27] software developed by Statistical Analysis Systems (SAS) (Cary, NC) was used to determine significant differences between treatment means at a significance level of 0.05 . Runoff volume data was found to be normal. Consequently, one way analysis of variance (ANOVA) was performed using general linear model (GLM) to determine significant differences between the runoff volume means of all treatments. Significant differences between runoff volume means of different treatment pairs were compared using the Tukey Kramer procedure. Turbidity and MTSS data were found to be non-normal. Therefore, the non-parametric Kruskal Wallis Rank Sum Test was used. Kruskal Wallis test is a non-parametric alternative to one way ANOVA. Wilcoxon non-parametric multiple comparison tests were also performed to determine significant difference between pairs of treatment means for turbidity and MTSS. The significance between correlated slopes of seeded versus nonseeded treatments was determined using Stat Graphics software [28] developed by Stat point Technologies (Warrenton, VA).

Graphical analysis was performed to evaluate the effect of percent vegetation on runoff response and to compare all seeded and non-seeded treatments as a function of days after seeding (DAS). Since no tall treatments received seeding, differences were evaluated based on equal time after seeding. Regression and correlation patterns for runoff volume, turbidity and MTSS were evaluated for significant response of seeded over non-seeded treatments. Significant differences would document water quality benefits of seeding in conjunction with other temporary covers.

Overall performance, maintenance and required labor can affect the overall cost of erosion control BMPs [29]. A cost database known as the Alabama Department of Transportation (ALDOT) item bid summary was used in this study represent construction industry costs in the southeast US. Mulching as defined in the ALDOT bid summary includes wheat and other straws blown as a dry mulch. The EFM treatment used in this study corresponds to type S3 ALDOT product per their approved list II-11 dated August 5, 2013. The ALDOT bid data was divided into counties within the state and averaged to obtain the mean cost per unit area of erosion and sediment control BMPs for Alabama. The most current ALDOT bid summary of March 6, 2014 was used as a reference for this analysis except for PAM cost which was available only from the ALDOT bid summary of October 1, 2012.

\section{Results and Discussion}

Average runoff volume from the test plots compared to a bare soil control (BS) are shown in Table 1. The treatment with the most effective volume reduction was EFM + S with an average runoff volume of $2873 \mathrm{ml}$ although not statistically different from WS + P + S with an average runoff volume of $4595 \mathrm{ml}$. EFM and WS + P were not statistically different with average runoff volume of $6265 \mathrm{ml}$ and $4873 \mathrm{ml}$, respectively. All cover treatments except BS + P reduced an average runoff volumes from $30 \%$ to $68 \%$, as compared to control. The ranking of treatments from most to least effective in terms of runoff reduction, as compared to control was: 1) $\mathrm{EFM}+\mathrm{S}(68.0 \%), 2) \mathrm{WS}+\mathrm{P}+\mathrm{S}(48.9 \%), 3) \mathrm{WS}+\mathrm{P}(45.8 \%), 4) \mathrm{EFM}(30.3 \%)$, and 5) BS + P (15.6\%). Bare soil with PAM only did not perform well compared to the mechanical covers likely due to the degradation of chemical after several simulated storms, the relatively low application rate, and the relative lack of surface 
roughness compared to other cover treatments. Runoff volume for the EFM $+\mathrm{S}$ treatment was significantly lower than the EFM and WS + P treatments. Consequently, vegetation was observed to have a significant impact on runoff volume reduction as expected. However, no statistical significance was observed between the two wheat straw treatments indicating that vegetation in wheat straw treatments had less effect on runoff volume than for the hydraulic mulch.

Table 2 presents the average turbidity from test plots compared to a bare soil control. The engineered fiber matrix (EFM) with and without seed was observed to reduce average turbidity levels to below 100 NTU. The WS + P treatment had higher NTU values than any other cover treatment except BS + P treatment. EFM was a more effective turbidity reduction treatment than wheat straw [30]. EFM + S was the most effective cover treatment evaluated, with an average runoff turbidity of $38 \mathrm{NTU}$ which was significantly lower than any other treatment. All cover treatments except BS + P were able to reduce the turbidity by more than $90 \%$, as compared to bare soil. Results were ranked from most to least effective turbidity reduction treatments compared to a bare soil control as: 1) EFM + S (98.7\%), 2) EFM (98.3\%), 3) WS + P + S (96.5\%), 4) WS + P (92.4\%), and 5) BS + $\mathrm{P}(16.9 \%)$. The application of PAM only was not effective in turbidity reduction at the rate used in this study (10 $\left.\mathrm{kg} \cdot \mathrm{ha}^{-1}\right)$.

Table 3 illustrates the average MTSS delivered from test plots compared to a bare soil control. Results indicated nearly 100 percent reduction of sediment delivery by all cover treatments except the BS $+\mathrm{P}$ treatment. The EFM and WS + P + S treatments were not statistically different with an average MTSS of $0.68 \mathrm{~g}$ and $0.97 \mathrm{~g}$, respectively. The WS + P treatment with an average MTSS of $1.48 \mathrm{~g}$ performed as well as WS + P + S treatment. $\mathrm{EFM}+\mathrm{S}$ with an average MTSS of $0.59 \mathrm{~g}$ was the most effective sediment reduction treatment with significantly lower sediment yield than any other treatment. The effectiveness of treatments were ranked from the most effective to least effective with reduction, as compared to a bare soil control: 1) EFM + S (99.8\%), 2) EFM (99.7\%), 3) WS + P + S (99.6\%), 4) WS + P (99.4\%), 5) BS + P (22.6\%). Mulch reduced soil erosion between $78 \%$ to $98 \%$ in review of 200 studies [31]. EFM sediment delivery was significantly lower than WS + P due to variable surface contact of the wheat straw. Neither of the wheat straw treatments were significant from each other indicating that the vegetation in wheat straw have less of an effect on average MTSS in straw mulch covers. The sediment delivery of BS and BS + P treatment were not significantly different from each other due to relatively low application rate of PAM used in this study $\left(10 \mathrm{~kg} \cdot \mathrm{ha}^{-1}\right)$.

Table 1. Average runoff volume results for surface runoff.

\begin{tabular}{ccc}
\hline Treatments $^{[\mathrm{a}]}$ & Average runoff volume (ml) & Reduction $^{\text {[b] }}$ \\
\hline BS & $8985^{\mathrm{a}}$ & - \\
BS + P & $7584^{\mathrm{a}, \mathrm{b}}$ & $3.6 \%$ \\
EFM & $6265^{\mathrm{b}, \mathrm{c}}$ & $30.3 \%$ \\
EFM + S & $2873^{\mathrm{d}}$ & $68.0 \%$ \\
WS + P & $4873^{\mathrm{c}}$ & $45.8 \%$ \\
WS + P + S & $4595^{\mathrm{c,d}}$ & $48.9 \%$ \\
\hline
\end{tabular}

Note: Treatments with same letters are not significantly different at $\alpha=0.05$; ${ }^{\text {[a] }}$ EFM-(Engineered Fiber Matrix), EFM + S-(EFM with seed), WS $+\mathrm{P}$-(Wheat Straw with PAM), WS + P + S-(WS + P with PAM and seed), BS + P-(Bare soil with PAM), BS-(Bare Soil); ${ }^{[b]}$ Percent reduction in turbidity compared to control.

Table 2. Average turbidity results for surface runoff.

\begin{tabular}{ccc}
\hline Treatments $^{[a]}$ & Average turbidity (NTU) & Reduction $^{[\mathrm{b}]}$ \\
\hline BS & $2946^{\mathrm{a}}$ & - \\
BS + P & $2449^{\mathrm{a}}$ & $16.9 \%$ \\
EFM & $51^{\mathrm{d}}$ & $98.3 \%$ \\
EFM + S & $38^{\mathrm{e}}$ & $98.7 \%$ \\
WS + P & $224^{\mathrm{b}}$ & $92.4 \%$ \\
WS + P + S & $103^{\mathrm{c}}$ & $96.5 \%$ \\
\hline
\end{tabular}

Note: Treatments with same letters are not significantly different at $\alpha=0.05$; ${ }^{[\mathrm{a}]} \mathrm{EFM}$-(Engineered Fiber Matrix), EFM + S-(EFM with seed), WS + $\mathrm{P}$-(Wheat Straw with PAM), WS + P + S-(WS + P with PAM and seed), BS + P-(Bare soil with PAM), BS-(Bare Soil); ${ }^{[b]}$ Percent reduction in turbidity compared to control. 
Table 3. Average MTSS results for surface runoff.

\begin{tabular}{ccc}
\hline Treatments $^{[\mathrm{a}]}$ & Average MTSS (g) & Reduction $^{[\mathrm{b}]}$ \\
\hline BS & $235^{\mathrm{a}}$ & - \\
BS + P & $182^{\mathrm{a}}$ & $99.6 \%$ \\
EFM & $0.68^{\mathrm{c}}$ & $99.7 \%$ \\
EFM + S & $0.59^{\mathrm{d}}$ & $99.4 \%$ \\
WS + P & $1.48^{\mathrm{b}}$ & $99.6 \%$ \\
WS + P + S & $0.97^{\mathrm{c}, \mathrm{b}}$ & \\
\hline
\end{tabular}

Note: Treatments with same letters are not significantly different at $\alpha=0.05$; ${ }^{[a]} E F M-$ (Engineered Fiber Matrix), EFM $+S-$ (EFM with seed), WS + $\mathrm{P}$ - (Wheat Straw with PAM), WS + P + S-(WS + P with PAM and seed), BS + P-(Bare soil with PAM), BS-(Bare Soil); ${ }^{[b]}$ Percent reduction in turbidity compared to control.
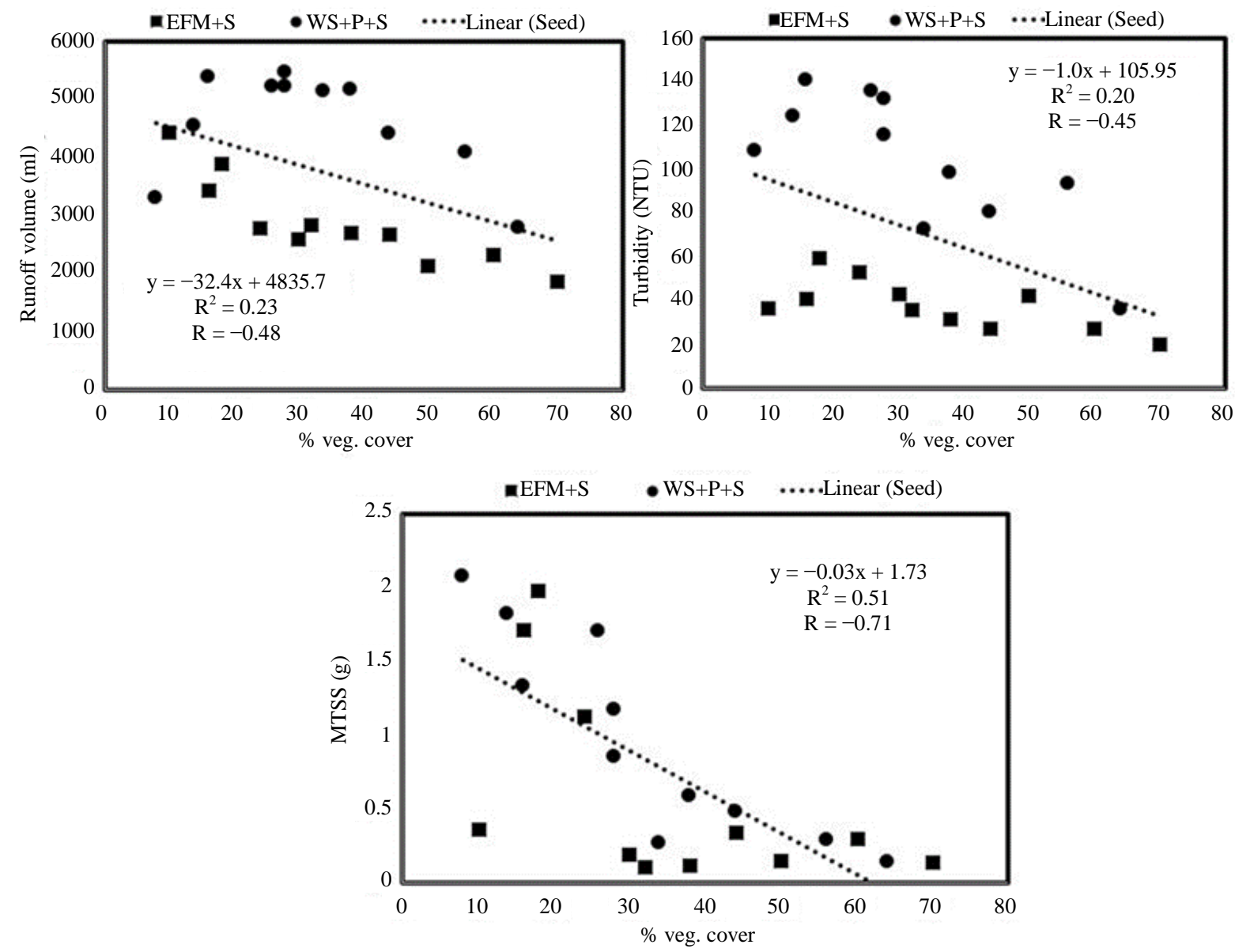

Figure 3. Effect of percent vegetation cover on runoff parameters (runoff volume, turbidity, and MTSS).

Figure 3 presents the effects of increased percent vegetation cover on plot runoff water quality and confirms a declining trend in runoff volume with increase in percent vegetation cover $(r=-0.48)$, as expected. Numerous studies report similar runoff reduction with increase in percent vegetation cover [32] [33]. The correlation coefficient $(r=-0.45)$ between turbidity of seeded treatments and percent vegetation cover indicates similar turbidity reduction with an increase in percent vegetation cover. The impact of increased percent vegetation on MTSS reduction was even more impressive $(r=-0.71)$, as also reported by other researchers [21] [22] due to increased surface roughness and the physical and mechanical interception of flow by vegetation. 


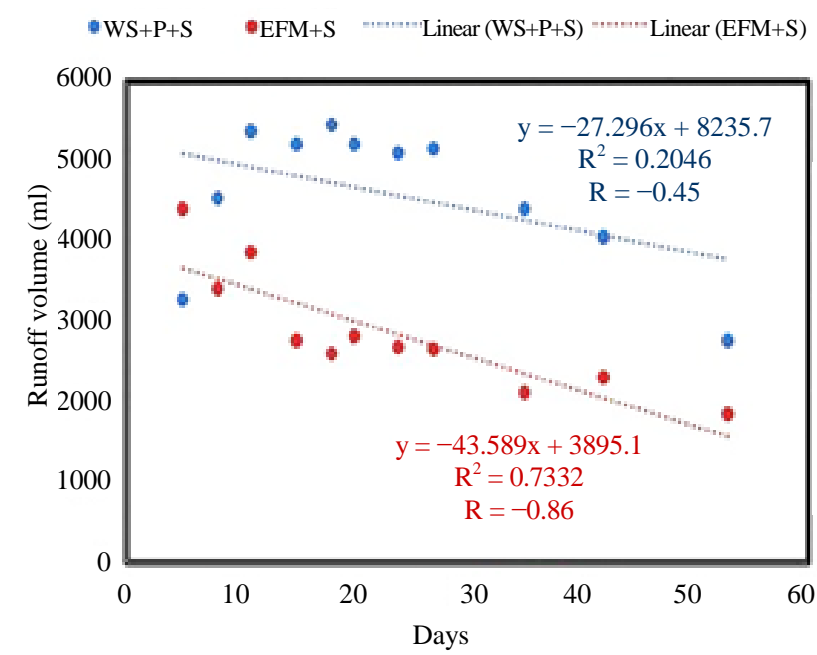

- $\mathrm{WS}+\mathrm{P} \quad$ EFM $\quad \cdots \cdots \cdots \cdot$ Linear (WS+P) $\cdots \cdots \cdots+$ Linear (EFM)
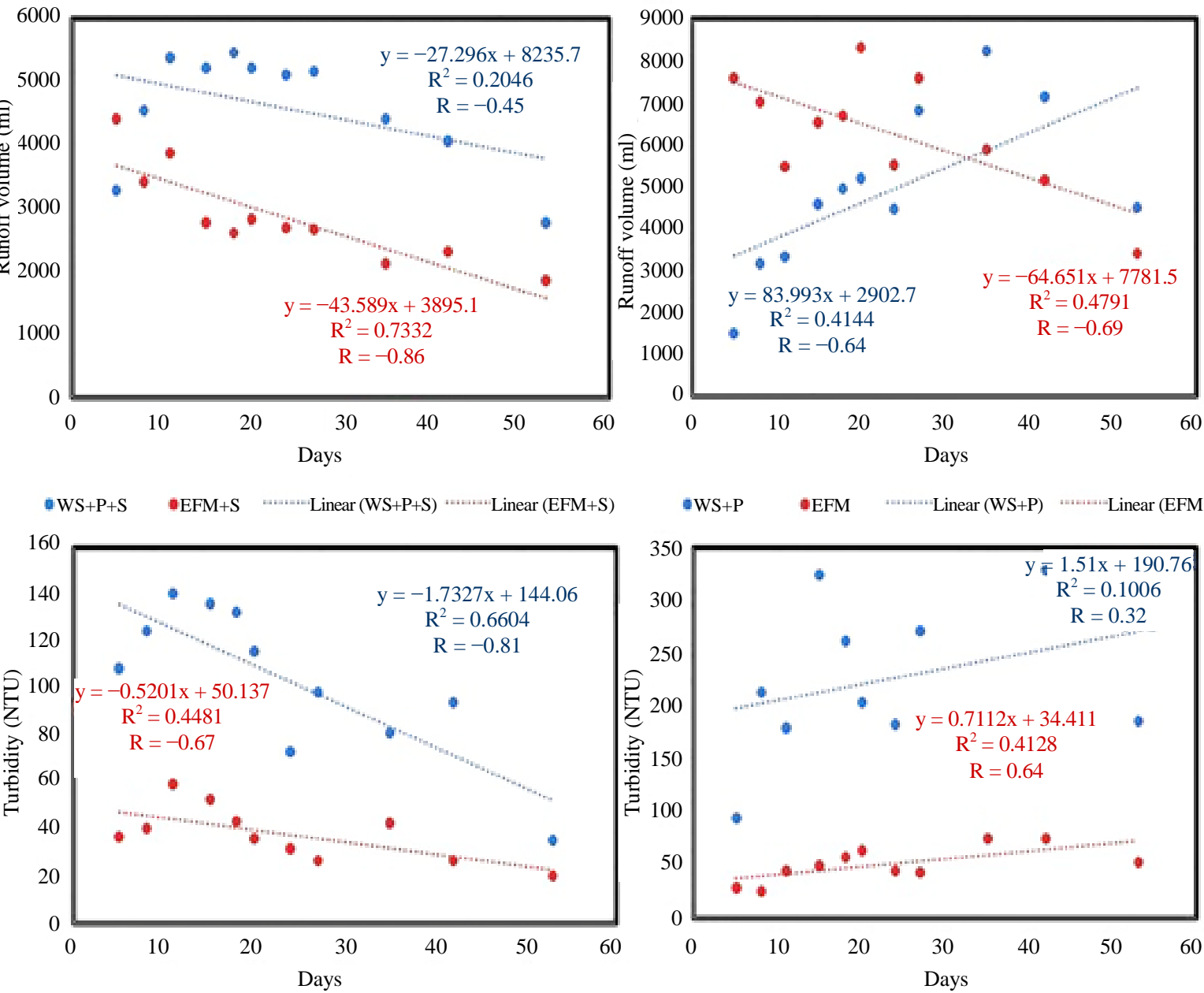

$\bullet \mathrm{WS}+\mathrm{P}+\mathrm{S} \quad \bullet \mathrm{EFM}+\mathrm{S} \quad \cdots \cdots \cdots$ Linear $(\mathrm{WS}+\mathrm{P}+\mathrm{S}) \cdots \cdots$ Linear $(\mathrm{EFM}+\mathrm{S})$
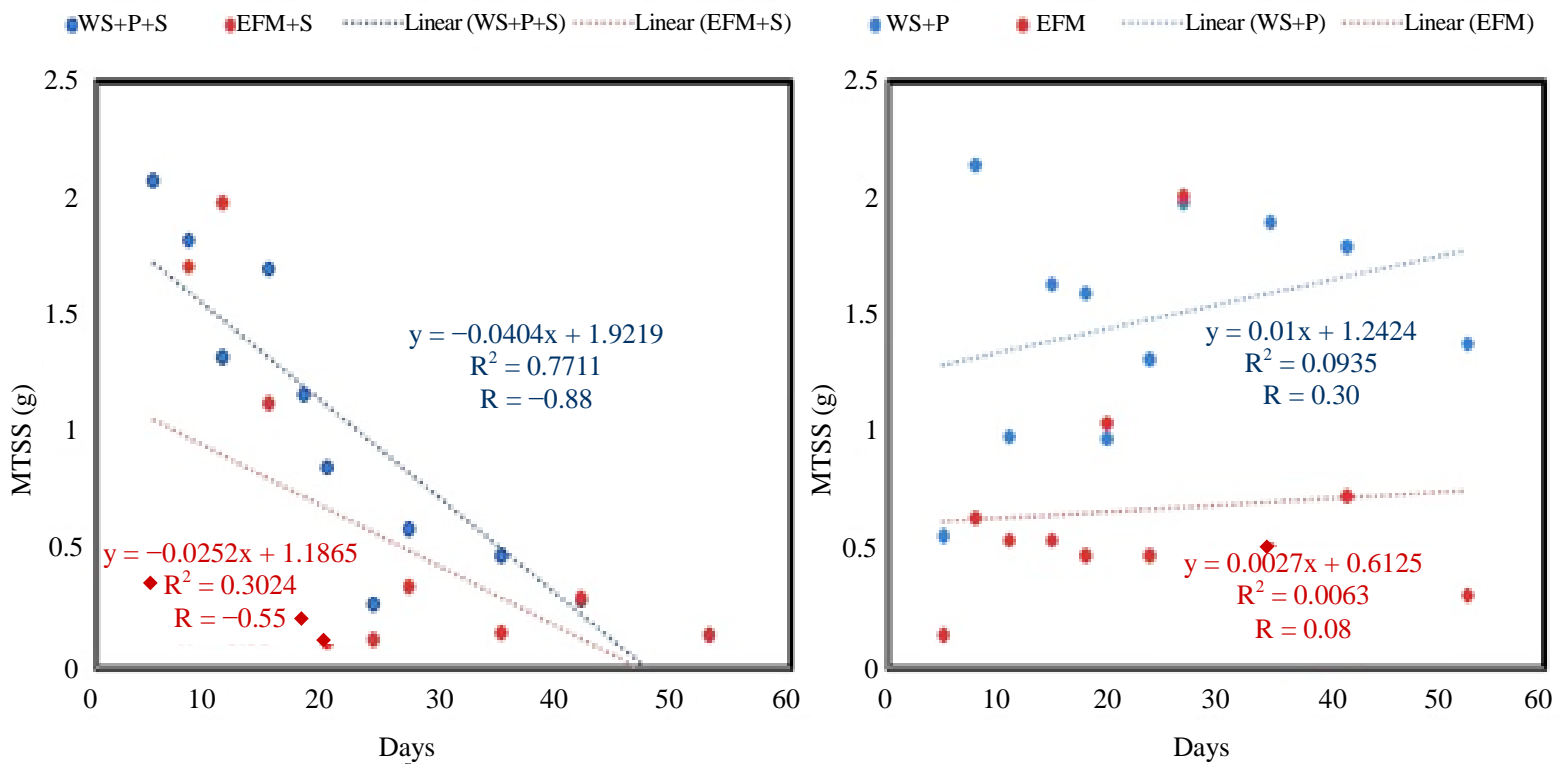

Figure 4. Comparison of seeded and nonseeded treatments with days (runoff volume, turbidity, and MTSS). 
Regression and correlation patterns for runoff volume, turbidity and MTSS delivered confirmed the expected response of seeded treatments over non-seeded treatments (Figure 4).

Figure 4 provide evidence of water quality benefits from seeding in conjunction with other temporary covers. The runoff volume of seeded treatments (WS $+\mathrm{P}+\mathrm{S}$ and EFM $+\mathrm{S})$ correlate negatively $(\mathrm{r}=-0.45$ and -0.86 , respectively) as compared to the rising response of non-seeded $(\mathrm{WS}+\mathrm{P})$ treatment $(\mathrm{r}=0.64)$ over time. The vegetation intercepts rainfall, which results in lower runoff volume. The non-seeded EFM treatment performed consistently well in terms of runoff volume reduction. The correlation between seeded treatments (WS + P + S and $\mathrm{EFM}+\mathrm{S})$ and days in terms of turbidity was also negative $(\mathrm{r}=-0.81$ and -0.67 , respectively) versus a positive correlation for non-seeded treatments ( $r=0.32$ and 0.64 for WS + P and EFM, respectively). Root structure of the vegetation strengthens the soil, keeping sediment in place. The MTSS response of WS + P + S and EFM + $\mathrm{S}$ also correlated negatively having $\mathrm{r}=-0.88$ and -0.55 , respectively, with days. MTSS delivery of non-seeded treatments (WS $+\mathrm{P}$ and EFM) increases over time ( $\mathrm{r}=0.30$ and 0.08 , respectively). The vegetation helps restrict the sediment movement from one place to another, thus reducing the soil loss. Therefore, the vegetation was helpful in reducing all water quality responses over time in combination with other temporary erosion control covers.

Table 4 presents the resulting cost analysis is for all temporary seeded and non-seeded cover treatments analyzed in this study. Reduction in MTSS delivered per plot compared to a bare soil control was converted to $\mathrm{kg} \cdot \mathrm{ha}^{-1}$. The cost of each treatment derived from the ALDOT biditem summary in $\$ \mathrm{ha}^{-1}$ was divided by $\mathrm{kg} \cdot \mathrm{ha}^{-1}$ MTSS reduction values to determine the dollars pent per $\mathrm{kg}$ of MTSS reduction. Results indicate that the BS + P treatment was the most cost-effective cost treatment per dollar of sediment delivery reduction with $\$ 0.38$ spent for each $\mathrm{kg}$ of sediment reduced compared to bare soil. However, as BS + P sediment delivery was not found significantly different from the bare soil control. BS + P is not considered beneficial as a water quality protection BMP at the application rate used in this study $\left(10 \mathrm{~kg} \cdot \mathrm{ha}^{-1}\right)$. The next most cost effective treatment was WS + P $\left(\$ 0.67 \mathrm{~kg}^{-1}\right)$ which can be recommended where quick inexpensive cover is needed for eroded slope stabilization, but regular disturbance does not justify the cost of seeding. EFM treatments, significantly more expensive than wheat straw treatments can be used for slopes adjacent to the sensitive environmental areas requiring quick stabilization to prevent water quality degradation. Seeded treatments (WS + P $+\mathrm{S}$, EFM + S) provide a long term alternative for slope stabilization and erosion control on disturbed sites [4]. Because neither of the seeded treatments (WS + P + S and EFM + S) were significantly different from each other in terms of percent cover establishment, differences in cost of MTSS reduction were used to quantify the most beneficial BMP in terms of cost and water quality benefits. EFM $+\mathrm{S}$ delivered 39\% less MTSS ha ${ }^{-1}$ than $\mathrm{WS}+\mathrm{P}+\mathrm{S}$, however WS $+\mathrm{P}+\mathrm{S}\left(\$ 3657 \mathrm{ha}^{-1}\right)$ is approximately $84 \%$ less expensive than EFM $+\mathrm{S}$ $\left(\$ 22,594 \mathrm{ha}^{-1}\right)$. Consequently, unless there is a special requirement for hydro-applied product, EFM $+\mathrm{S}$ does not appear as economical to use when almost the same level of performance can be achieved with WS $+\mathrm{P}+\mathrm{S}$. $\mathrm{WS}+\mathrm{P}+\mathrm{S}$ can therefore be considered as a more cost effective option compared to EFM $+\mathrm{S}$ in terms of water quality protection via reduced sediment delivery, under similar slope, soil and rainfall conditions of this study. Results of this plot scale study cannot necessarily be extrapolated directly to field scale application.

Table 4. Average cost comparison of erosion control BMPs in terms of sediment reduction.

\begin{tabular}{|c|c|c|c|c|c|c|}
\hline & BS & $\mathrm{BS}+\mathrm{P}$ & $\mathrm{WS}+\mathrm{P}$ & $W S+P+S$ & EFM & $\mathrm{EFM}+\mathrm{S}$ \\
\hline MTSS/plot (g) & 235 & 182 & 1.48 & 0.97 & 0.68 & 0.59 \\
\hline MTSS (kg/ha) & 3561 & 2758 & 22 & 15 & 10 & 9 \\
\hline MTSS reduction $(\mathrm{kg} / \mathrm{ha})^{[\mathrm{a}]}$ & 0 & 803 & 3538 & 3546 & 3550 & 3552 \\
\hline Cost $/ \mathrm{ha}^{[\mathrm{b}]}$ & NA & $\$ 307^{[c]}$ & $\$ 2369$ & $\$ 3657$ & $\$ 21,306$ & $\$ 22,594$ \\
\hline Dollar/sediment reduction (\$/kg) & NA & $\$ 0.38$ & $\$ 0.67$ & $\$ 1.03$ & $\$ 6.00$ & $\$ 6.36$ \\
\hline
\end{tabular}

${ }^{[\mathrm{ad}]}$ Reduction compared to abaresoil control; ${ }^{[\mathrm{b}]}$ ALDOT item bid summary, 2014; ${ }^{[\mathrm{cc}}$ ALDOT bid summary, 2012. 


\section{Conclusion}

The main objective of the study was to evaluate and compare the erosion control performance of five erosion control covers (EFM, EFM + S, WS + P, WS + P + S and BS + P) under simulated rainfall compared to a bare soil (BS) control with respect to water quality response (runoff volume, turbidity and MTSS delivery). The application of PAM at the low application rate used in this study $\left(10 \mathrm{~kg} \mathrm{ha}^{-1}\right)$ was not effective in erosion control. The seeded EFM + S and WS + P + S treatments were observed to be the most effective in terms of runoff volume, while the seeded EFM + S treatment was the most effective treatment with respect to turbidity and MTSS. The runoff response of seeded treatments (EFM + S and WS + P + S) have declining trend over time as compared to rising or flat runoff response of non-seeded treatments (EFM and WS $+\mathrm{P})$. These findings documented the important water quality benefit of seeding as an erosion control practice. The WS + P + S treatment was significantly less expensive than EFM + S treatment with similar water quality benefits. Consequently, wheat straw with PAM and seed can be recommended as a cost effective approach for slope stabilization under similar conditions used in this study. It can be concluded from results that vegetation is an important and cost effective sediment reduction parameter for stabilization of disturbed slopes. Future studies need to focus on longer vegetation establishment periods under natural rainfall and field scale conditions to better assess the cost effectiveness under more realistic conditions as limitations of the present study preclude direct field extrapolation.

\section{Acknowledgements}

Funding for this project was provided by Alabama General Contractors (AGC), Pittsview, AL. Special thanks to Earl Norton, Jim Harris, and Department of Biosystems Engineering staff, Auburn University, AL for assistance during the project.

\section{References}

[1] United States Department of Agriculture (USDA) (2014) Erosion. http://www.nrcs.usda.gov/wps/portal/nrcs/main/national/landuse/crops/erosion/

[2] United States Environmental Protection Agency (USEPA) (1994) What Is Non-Point Source Pollution? Questions and Answers. EPA-841-F94-005. http://www.epa.gov/owow/nps/qa.html.

[3] Zech, W., Mcdonald, J.S. and Clement, T.P. (2009) Field Evaluation of Siltfencetie Back System Satahigh Way Construction Site. Practice Periodicalon Structural Design \& Construction, 14, 105-112. http://dx.doi.org/10.1061/(ASCE)1084-0680(2009)14:3(105)

[4] Pitt, R., Clark, E. and Lake, W. (2007) Construction Site Erosion and Sediment Controls: Planning, Design and Performance. DEStech Publications, Lancaster.

[5] Grace, J.M. (2000) Forest Road Side Slopes and Soil Conservation Techniques. Journal of Soil and Water Conservation, 55, 96-101.

[6] Bochet, E. and Garcia Fayos, P. (2004) Factors Controlling Vegetation Establishment and Water Erosiononmotor Way Slopes in Valencia, Spain. Restoration Ecology, 12, 166-174. http://dx.doi.org/10.1111/j.1061-2971.2004.0325.X

[7] United States Environmental Protection Agency (USEPA) (2005) National Management Measures to Control Nonpoint Source Pollution from Urban Areas. http://water.epa.gov/polwaste/nps/urban/upload/urban_guidance.pdf

[8] Foltz, R.B. and Dooley, J.H. (2003) Comparison of Erosion Reduction between Wood Strands and Agricultural Straw. Transactions of the ASABE, 46, 1389-1396.

[9] Wilson, W. (2010) Evaluation of Hydromulches as an Erosion Control Measure Using Intermediate-Scale Experiments. M. S. Diss, Auburn University, Auburn.

[10] Groen, H. and Woods, S.W. (2008) Effectiveness of Aerial Seeding and Strawmulch for Reducing Post-Wildfire Erosion, North-Western Montana, USA. International Journal of Wildland Fire, 17, 559-571. http://dx.doi.org/10.1071/WF07062

[11] Benik, S., Wilson, B., Biesboer, D. and Hansen, B. (2003) Performance of Erosion Control Products on a High Way Embankment. Transactions of the ASAE, 46, 1113-1119. http://dx.doi.org/10.13031/2013.13962

[12] Lipscomb, C.M., Johnson, T., Nelson, R. and Lancaster, T. (2006) Comparison of Erosion Control Technologies: Blown Straw vs. Erosion Control Blankets.

http://www.americanexcelsior.com/erosioncontrol/library/Technical\%20Papers/Blown\%20Straw\%20vs.\%20Erosion\% 20Control\%20Blankets.pdf

[13] Babcock, D. and Mc Laughlin, R. (2008) Soil Facts: Mulch Options for Erosion Control on Construction Sites. 
http://content.ces.ncsu.edu/20431.pdf

[14] Mc Laughlin, R.A. and Brown, T.T. (2006) Evaluation of Erosion Control Products with and without Added Polyacrylamide. Journal of the American Water Resources Association, 42, 675-684. http://dx.doi.org/10.1111/j.1752-1688.2006.tb04484.x

[15] Babcock, D.L. and McLaughlin, R.A. (2011) Runoff Water Quality and Vegetative Establishment for Groundcovers on Steep Slopes. Journal of Soil and Water Conservation, 66, 132-141. http://dx.doi.org/10.2489/jswc.66.2.132

[16] Shoemaker, A.L. (2009) Evaluation of Anionic Polyacrylamide as an Erosion Control Measure Using IntermediateScale Experimental Procedures. Master’s Thesis, Auburn University, Auburn.

[17] Soupir, M.L., Mostaghimi, S., Masters, A., Flahive, K.A., Vaughan, D.H., Mendez, A. and McClellan, P.W. (2004) Effectiveness of Polyacrylamide (PAM) in Improving Runoff Water Quality from Construction Sites. Journal of the American Water Resources Association, 40, 53-66. http://dx.doi.org/10.1111/j.1752-1688.2004.tb01009.x

[18] Flanagan, D.C. and Canady, N.H. (2006) Use of Polyacrylamide in Simulated Land Application of Lagoon Effluent: Part I. Runoff and Sediment Loss. Transactions of the ASABE, 49, 1361-1369. http://dx.doi.org/10.13031/2013.22052

[19] Roa-Espinosa, A., Bubenzer, G.D. and Miyashita, E.S. (1999) Sediment and Runoff Control on Construction Sites Using Four Application Methods of Polyacrylamidemix. ASAE Paper No. 99, ASAE, St. Joseph.

[20] Gyssels, G., Poesen, J., Bochet, E. and Li, Y. (2005) Impact of Plant Roots on the Resistance of Soils to Erosion by Water: A Review. Progress in Physical Geography, 29, 189-217. http://dx.doi.org/10.1191/0309133305pp443ra

[21] Pan, C.Z. and Shangguan, Z.P. (2006) Runoff Hydraulic Characteristics and Sediment Generation in Sloped Grass Plots under Simulated Rainfall Conditions. Journal of Hydrology, 331, 178-185. http://dx.doi.org/10.1016/j.jhydrol.2006.05.011

[22] Liu, G., Tian, F.X., Warrington, D.N., Zheng, S.Q. and Zhang, Q. (2010) Efficacy of Grass for Mitigating Runoff and Erosion from an Artificial Loessial Earthen Road. Transactions of the ASABE, 53, 119-125.

[23] Hudson, N. (1993) Field Measurement of Soil Erosion and Runoff. 68th Edition, Food and Agricultural Organization of United Nations Publications, Rome.

[24] The Irrigation Association (2002) Certified Irrigation Contractor Work Book. The Irrigation Association Publications, Falls Church.

[25] ASWCC, Alabama Soil and Water Conservation Committee (2009) Alabama Handbook for Erosion Control, Sediment Control, and Storm Water Management on Construction Site and Urban Areas.

[26] USEPA, United States Environmental Protection Agency (1999) Method 160.2. Methods for Chemical Analysis of Water and Wastes. http://www.caslab.com/EPA-Methods/PDF/EPA-Method-160-2.pdf

[27] Statistical Analysis Software, SAS (2014) JMP11 Software. Version 9.2, SAS Institute Inc., Cary.

[28] Statpoint Technologies Inc. (2014) Statgraphics Centurion XVII. Warrenton.

[29] Donald, W. (2013) Performance Evaluations on Ditch Check Practices and Products for Channelized Stormwater Runoff Control Using Large-Scale Testing. Ph. D. Dissertation, Auburn University, Auburn.

[30] Babcock, D. and McLaughlin, R. (2013) Erosion Control Effectiveness of Straw, Hydromulch, and Polyacrylamide in a Rainfall Simulator. Journal of Soil and Water Conservation, 68, 221-227. http://dx.doi.org/10.2489/jswc.68.3.221

[31] Doolette, J.B. and Smyle, J.W. (1990) Soil and Moisture Conservation Technologies: Review of Literature. In: Doolette, J.B. and Magrath, W.B., Eds., Watershed Developments in Asia: Strategies and Technologies, World Book Technical Paper No. 127, Washington DC, 35-69.

[32] Adekalu, K., Olorunfemi, I. and Osunbitan, J. (2007) Grass Mulching Effect on Infiltration, Surface Runoff and Soil Loss of Three Agricultural Soils in Nigeria. Bioresource Technology, 98, 912-917. http://dx.doi.org/10.1016/j.biortech.2006.02.044

[33] Foltz, R.B. and Copeland, N.S. (2009) Evaluating the Efficacy of Wood Shreds for Mitigating Erosion. Journal of Environmental Management, 90, 779-785. http://dx.doi.org/10.1016/j.jenvman.2008.01.006 
Scientific Research Publishing (SCIRP) is one of the largest Open Access journal publishers. It is currently publishing more than 200 open access, online, peer-reviewed journals covering a wide range of academic disciplines. SCIRP serves the worldwide academic communities and contributes to the progress and application of science with its publication.

Other selected journals from SCIRP are listed as below. Submit your manuscript to us via either submit@scirp.org or Online Submission Portal.
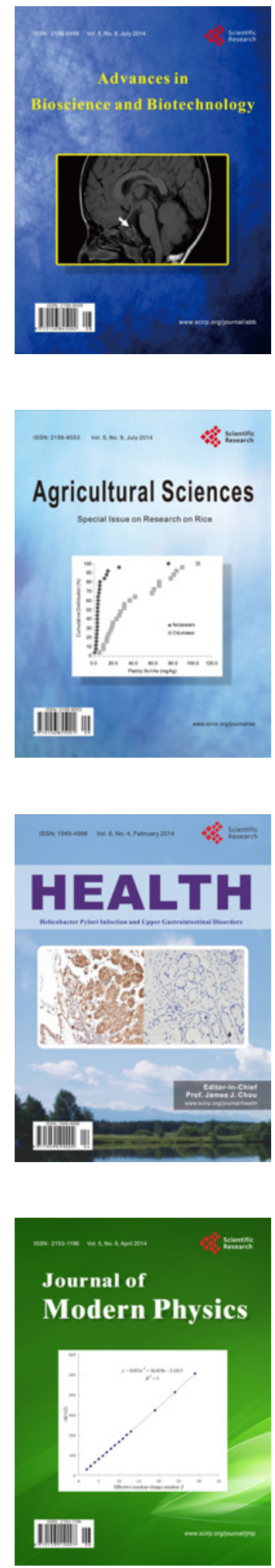
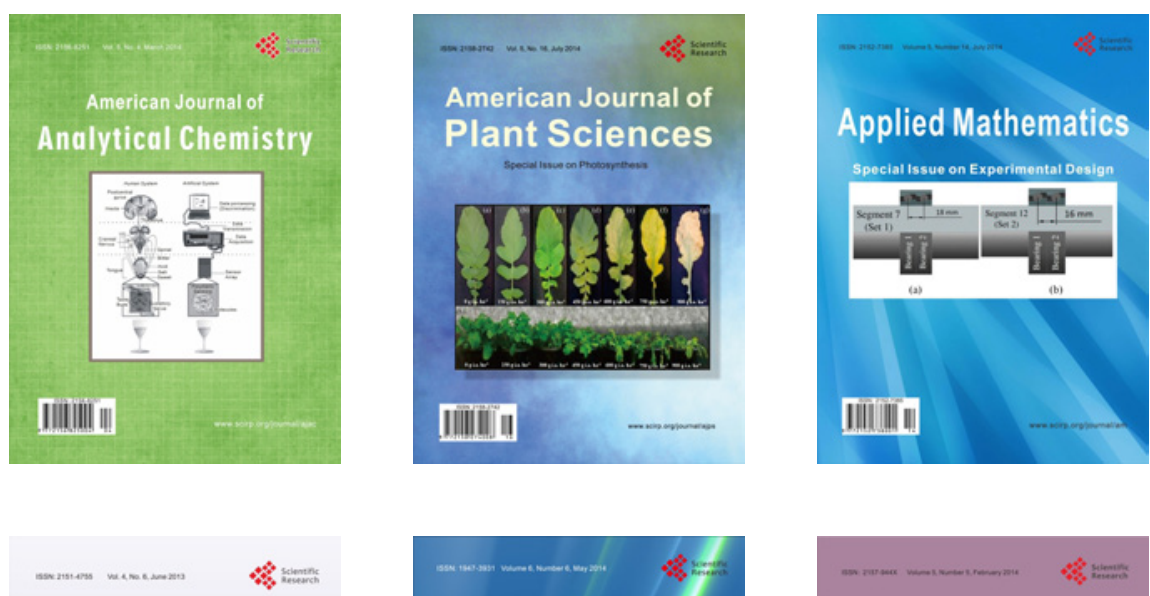

Creative Education
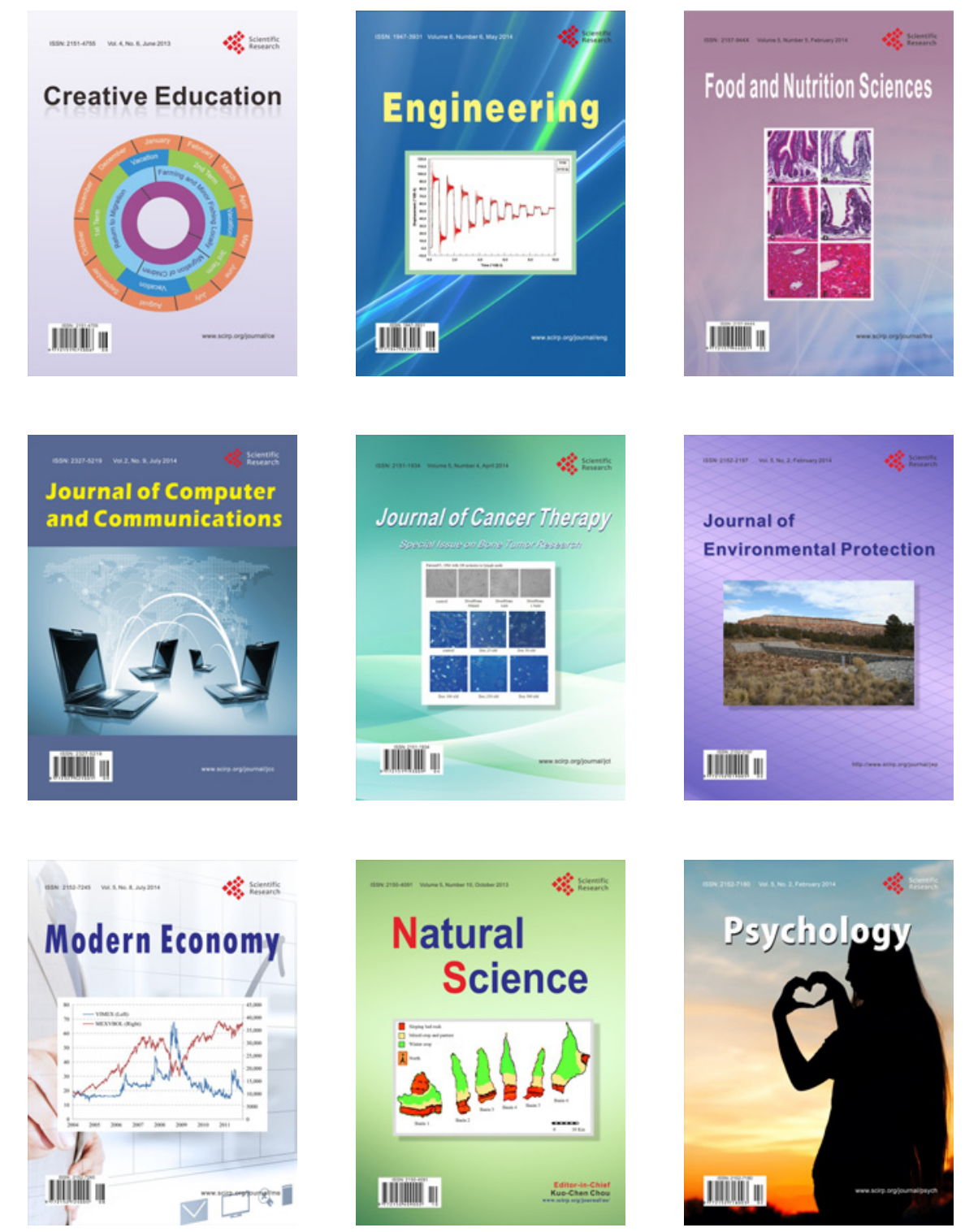